Original Article

\title{
Study of Treadmill Exercise Effect on Rats with Osteoarthritis Using Proteomic Analysis
}

\author{
Sang Su Na, PT, MS ${ }^{1)}$, SeOng Gil Kim, PT, MS ${ }^{1)}$, Min Sik Yong, PT, MS ${ }^{1)}$, \\ GaK Hwangbo, PT, $\left.\mathrm{PhD}^{2}\right)^{*}$ \\ 1) Department of Rehabilitation Science, Graduate School, Daegu University, Republic of Korea \\ 2) Department of Physical Therapy, College of Rehabilitation Science, Daegu University: 15 Jillyang, \\ Gyeongsan-si, Gyeongbuk 712-714, Republic of Korea
}

\begin{abstract}
Purpose] To investigate the correlation between the effect treadmill exercise and change in serum proteins in rats with osteoarthritis, a study of proteins was carried out using a mass spectrometer. [Subjects and Methods] Rats were randomly divided into five groups. After 4 weeks of treadmill training, serum from each rat was analyzed by Liquid chromatography-electrospray ionization tandem mass spectrometry. Complementary component 9 (C9) was discovered to be downregulated in the serum of the exercise groups, and this was validated by Western blot. [Results] Seventeen proteins were discovered to be elevated in the monosodium iodoacetate injection osteoarthritis group samples by more than 1.5 fold compared with the control group. One of the proteins upregulated, C9 protein, was validated, and it was found to decrease in the middle-intensity exercise group. [Conclusion] We showed that the serum level of $\mathrm{C} 9$, an inflammatory-related protein, decreased after treadmill exercise. Therefore, treadmill exercise with an appropriate intensity might be recommended for OA patients.

Key words: Treadmill, Serum protein, Proteomics
\end{abstract}

(This article was submitted Sep. 9, 2013, and was accepted Oct. 16, 2013)

\section{INTRODUCTION}

As the longevity of humans increases, osteoarthritis (OA) has become a frequent disorder among older adults. $\mathrm{OA}$ is a disorder with a multifactorial origin that involves the articular cartilage, synovium, subchondral bone, ligaments, and/or the neuromuscular apparatus. OA causes pain, disability, and reduced quality of life. There are many risk factors for the progression of knee OA, which include age, previous injury, increased body mass index (BMI), genetic factors, and high workload ${ }^{1}$.

Several studies have suggested that exercises such as joint-specific strength and general aerobic conditioning are generally recommended for OA treatment ${ }^{2}$. Also, several studies have shown that increased muscle strength provides joint stability and reduces pain and disability ${ }^{3,4)}$. Physical therapy programs are often prescribed to patients with knee OA. The expected benefits of these programs include reduction in pain, improved function, and altered joint load ${ }^{5,6)}$.

Fragments of structural proteins can be detected in serum as the reflection of cartilage degeneration. Numerous studies have reported the discovery of putative biomarkers in blood using a mass spectrometer ${ }^{7,8)}$. There are three com-

*Corresponding author. Gak Hwangbo (E-mail: hbgak@ daegu.ac.kr)

(C2014 The Society of Physical Therapy Science. Published by IPEC Inc. This is an open-access article distributed under the terms of the Creative Commons Attribution Non-Commercial No Derivatives (by-ncnd) License $<$ http://creativecommons.org/licenses/by-nc-nd/3.0/> . monly used serum biomarkers associated and/or correlated with $\mathrm{OA}$ and joint progression: antigenic keratin sulfate $(\mathrm{AgKS})^{9}$ ), hyaluronan $(\mathrm{HA})^{10,11)}$, and cartilage oligomeric matrix protein (COMP) ${ }^{12)}$.

In this study, the serum levels of proteins in rats with OA were considered to reflect the level of systemic inflammation. Therefore, we investigated the changes in serum protein levels by proteomic analysis and confirmed one of the inflammatory proteins, C9. In addition, we further investigated the correlation between specific inflammatory protein levels and treadmill exercise.

\section{SUBJECTS AND METHODS}

Adult male Sprague-Dawley rats $(8-10$ weeks of age, weighing $250-300 \mathrm{~g}, \mathrm{n}=30$ ) were housed at $22{ }^{\circ} \mathrm{C}$ under a 12:12-h light-dark cycle and had access to food and water ad libitum.

MIA (monosodium iodoacetate, Sigma, St. Louis, MO, USA cat \#I2512) was used to induce arthritis as previously reported $^{13,14)}$.

Rats were randomly divided into five groups: (1) no MIA injection or exercise group (control group, $\mathrm{n}=10$ ), (2) MIA injection without treadmill running exercise group (MIA injection group, $\mathrm{n}=10$ ), (3) MIA injection with low-intensity exercise group (LE, $\mathrm{n}=10$ ), (4) MIA injection with middle-intensity exercise group (ME, $\mathrm{n}=10$ ), and (5) MIA injection and with high-intensity exercise group (HE, $n=10)$. The running protocol was performed according to a modified version of Ueda's method ${ }^{15,16}$. All procedures followed Daegu University's guidelines and were approved by the 
Table 1. Proteins identified by LC-MS/MS analysis that increased in the MIA injection group by over 1.5 -fold

\begin{tabular}{|c|c|c|c|c|c|c|c|c|}
\hline Identified Proteins (17) & $\begin{array}{l}\text { Accession } \\
\text { Number }\end{array}$ & $\begin{array}{l}\text { Molecular } \\
\text { Weight }\end{array}$ & NA & MIA & $\mathrm{L}$ & M & $\mathrm{H}$ & $\begin{array}{c}\text { Fold } \\
\text { Change }\end{array}$ \\
\hline Gene_Symbol=C9 C9 protein & IPI00231423 & $64 \mathrm{kDa}$ & 0 & 3 & 0 & 0 & 0 & \\
\hline Gene_Symbol=Apoa4 Apolipoprotein A-IV & IPI00324272 & $44 \mathrm{kDa}$ & 0 & 12 & 7 & 0 & 7 & \\
\hline $\begin{array}{l}\text { Gene_Symbol=Serpinf } 2 \text { Serine (or cysteine) peptidase inhibitor, } \\
\text { clade F, member } 2\end{array}$ & IPI00199695 & $55 \mathrm{kDa}$ & 0 & 11 & 6 & 9 & 0 & \\
\hline Gene_Symbol=Serpina4 Kallistatin & IPI00205568 & $48 \mathrm{kDa}$ & 0 & 10 & 0 & 0 & 3 & e \\
\hline Gene_Symbol=Serpina3k Serine protease inhibitor A3 K & IPI00200593 & $47 \mathrm{kDa}$ & 18 & 64 & 33 & 34 & 39 & 3.557 \\
\hline Gene_Symbol=Ttr Transthyretin & IPI00324380 & $16 \mathrm{kDa}$ & 6 & 19 & 15 & 15 & 28 & 3.255 \\
\hline Gene_Symbol=LOC299282 Liver regeneration protein lrryan & IPI00392216 & $68 \mathrm{kDa}$ & 21 & 65 & 33 & 34 & 33 & 3.014 \\
\hline Gene_Symbol=C4b Complement $\mathrm{C} 4$ & IPI00213036 & $192 \mathrm{kDa}$ & 10 & 24 & 27 & 21 & 22 & 2.487 \\
\hline Gene_Symbol=Igh-6 Igh- 6 protein & IPI00368888 & $68 \mathrm{kDa}$ & 8 & 21 & 21 & 21 & 24 & 2.453 \\
\hline Gene_Symbol=Hp Isoform 2 of Haptoglobin & IPI00382202 & $42 \mathrm{kDa}$ & 8 & 21 & 19 & 23 & 27 & 2.453 \\
\hline Gene_Symbol=IgG-2a LOC367586 protein & IPI00361346 & $51 \mathrm{kDa}$ & 29 & 66 & 71 & 58 & 71 & 2.299 \\
\hline Gene_Symbol=Afm Afamin & IPI00207668 & $69 \mathrm{kDa}$ & 7 & 13 & 5 & 25 & 4 & 1.810 \\
\hline Gene_Symbol=LOC67870139 kDa protein & IPI00557598 & $39 \mathrm{kDa}$ & 6 & 11 & 14 & 9 & 13 & 1.809 \\
\hline Gene_Symbol=Plg Plasminogen & IPI00206780 & $91 \mathrm{kDa}$ & 11 & 18 & 15 & 26 & 9 & 1.709 \\
\hline Gene_Symbol=Itih3 Inter-alpha-trypsin inhibitor heavy chain H3 & IPI00326984 & $99 \mathrm{kDa}$ & 13 & 22 & 4 & 11 & 18 & 1.644 \\
\hline Gene_Symbol=F2 Prothrombin (fragment) & IPI00189981 & $70 \mathrm{kDa}$ & 5 & 8 & 0 & 5 & 0 & 1.582 \\
\hline Gene_Symbol=Hpx Hemopexin & IPI00195516 & $51 \mathrm{kDa}$ & 25 & 38 & 27 & 55 & 20 & 1.507 \\
\hline
\end{tabular}

Fold-change $=$ quantitative peptide hits of the MIA group/quantitative peptide hits of the control group

Institutional Animal Care and Use Committee (IACUC).

Liquid chromatography-tandem mass spectrometry (LCMS/MS) analysis was carried out using an LTQ mass spectrometer (Thermo Electron, San Jose, CA, USA) equipped with NSI sources (Thermo Electron, San Jose, CA), as previously reported ${ }^{17)}$. Briefly, $12 \mathrm{ul}$ of peptide sample from in-gel digestion was injected and loaded onto a peptide trap cartridge (Agilent, Palo Alto, CA, USA). Trapped peptides were eluted onto a $10-\mathrm{cm}$ RP PicoFrit column packed inhouse $\left(5 \mathrm{~mm}, 300 \mathrm{~A}^{\circ}\right.$ pore size, $\left.\mathrm{C} 18\right)$ and then separated by gradient elution. The mobile phases consisted of $\mathrm{H}_{2} \mathrm{O}$ (A) and $\mathrm{ACN}(\mathrm{B})$, and both contained $0.1 \% \mathrm{v} / \mathrm{v}$ formic acid. The flow rate was maintained at $200 \mathrm{~nL} / \mathrm{min}$. The spray voltage was $1.9 \mathrm{kV}$, and the temperature of the ion transfer tube was set at $195^{\circ} \mathrm{C}$. The gradient started at $2 \% \mathrm{~B}$ and reached $60 \% \mathrm{~B}$ in $50 \mathrm{~min}, 80 \% \mathrm{~B}$ in the next $5 \mathrm{~min}$, and $100 \% \mathrm{~A}$ in the final 15 min. Full MS spectra (MS survey scan) were recorded in the ion trap cell, and data-dependent MS/MS spectra for the five most intense ions were subsequently acquired by the LTQ under the $35 \mathrm{eV}$ of collision energy and an isolation with of $2 \mathrm{Da}$.

To validate C9 protein, we used Western blot analysis, which was performed as previously reported ${ }^{17)}$. A Western blot analysis system (Amersham Biosciences, Little Chalfont, Buckinghamshire, UK) was used to detect immunoreactive proteins. The thickness of the bands was photographically measured using Scion Image (Scion, Frederick, MD, USA). An image of a calibration grid slide was measured using Scion Image, and the distance of $250 \mathrm{~mm}$ was calculated to be equivalent to 733 pixels. One-way ANOVA was used to evaluate the statistical significance of differences among three or more groups. All analyses were done with Origin 8.0 , and $p$-values $\leq 0.05$ were considered statistically significant.

\section{RESULTS}

Blood samples were obtained from individuals with or without exercise followed by the serum collection protocol. Using 1-D SDS-PAGE, 40 ug proteins of pooled serum from each of the five groups were separated, and the gels were stained with Coomassie brilliant blue staining solution. To identify the proteins, gels were excised into five bands and subjected to in-gel digestion, and then tryptic peptides were analyzed by LC-ESI-MS/MS analysis.

The digested protein samples were run on an LC-ESIMS/MS. Table 1 shows the upregulated proteins identified by the LC-MS/MS analysis. Seventeen proteins showed significant elevation in the samples from the MIA injection group, with the levels being 1.5-fold higher than those of the control group (Table 1).

Among the 17 upregulated proteins, 9 proteins increased in the MIA injection group compared with both the control group and exercise applied groups: Complement component 9, Apolipoprotein A-IV, Serine peptidase inhibitor, Kallistatin, Serine protease inhibitor A3 K, Liver regeneration protein lrryan, Complement $\mathrm{C} 4$, Interalpha-trypsin inhibitor heavy chain H3, and Prothrombin (Table 1).

Among the list of proteins upregulated in the MIA injection group, C9 was first selected for validation because it was at the top of the list (Table 1). To validate the serum levels of $\mathrm{C} 9$, the protein levels were analyzed by Western blot analysis in a total 50 serum samples, which comprised samples from the control $(n=10)$, MIA injection $(n=10)$, LE $(n=10), \operatorname{ME}(n=10)$ and HE groups $(n=10)$. Figure 1A shows some representative Western blot results. 
In the results, C9 significantly decreased in the ME group compared with the MIA injection group; however, the $\mathrm{C}$ 9 level in the LE/HE groups did not show significant changes (Fig. 1B).

\section{DISCUSSION}

$\mathrm{OA}$ is a common chronic degenerative disease characterized by the loss of articular cartilage components due to many reasons. According to studies of OA biology, serum proteins could be evidence of OA state and useful for diagnosis.

The objective of this study was to determine the change in serum protein levels in a rat osteoarthritis model with or without exercise. Therefore, we investigated the proteome profiles in serum samples using LC-MS/MS. The proteome profile results showed that many serum protein levels were changed; some proteins were increased and others were decreased.

Among the upregulated proteins, 9 proteins showed increases compared with the control group and decreases in the exercise intervention group (Table 1). Among these 9 proteins, C9 is well known to be a terminal member in cell killing through the action of the membrane attack complex, which consists of $\mathrm{C} 5 \mathrm{~b}, \mathrm{C} 6, \mathrm{C} 7, \mathrm{C} 8$, and $\mathrm{C} 9^{18)}$. We focused on the change in $\mathrm{C} 9$ expression in the inflammation environment caused by MIA injection.

C9 validation was carried out by Western blot analysis. In the validation process, an individual sample was loaded, and detection was performed (Fig. 1A). The results showed that $\mathrm{C} 9$ expression in the MIA injection and 3 exercise groups changed significantly compare with the control group. Only the ME group showed a significantly reduced increase in C9 expression after MIA injection. Also, the C9 level of the ME group was significantly lower than those of the LE/HE groups. However, the LE and HE groups did not show significant decreases in the $\mathrm{C} 9$ level due to induction by MIA (Fig. 1B).

C9 is one of the proteins in the complement system, which is a well-known inflammatory-related pathway. During late complement pathway processes, which involve C5C9, the inflammation sites recruit $\mathrm{C} 5 \mathrm{a}$ by chemotaxis, and this leads to the formation of terminal complement complex $(\mathrm{TCC})^{19)}$. OA is a systemic inflammatory disease; therefore, the complement system may be an important effector system in various arthritides. Based on our results, it is possible that the $\mathrm{C} 9$ protein level was increased by the systemic response to the induced OA. Further, the increased level of C9 decreased due to exercise, which indicates improvement of the OA condition.

In several previous studies, OA cartilage degeneration was examined based on certain protein levels in the serum. In a previous study, the change in COMP concentration was measured, and significant change was reported ${ }^{20)}$. Still, more molecular biomarkers need to be investigated and studied. Therefore, investigation of whole serum proteins in rats with OA would provide supportive information for such biomarkers.

In this study, we analyzed whole serum proteins. How-

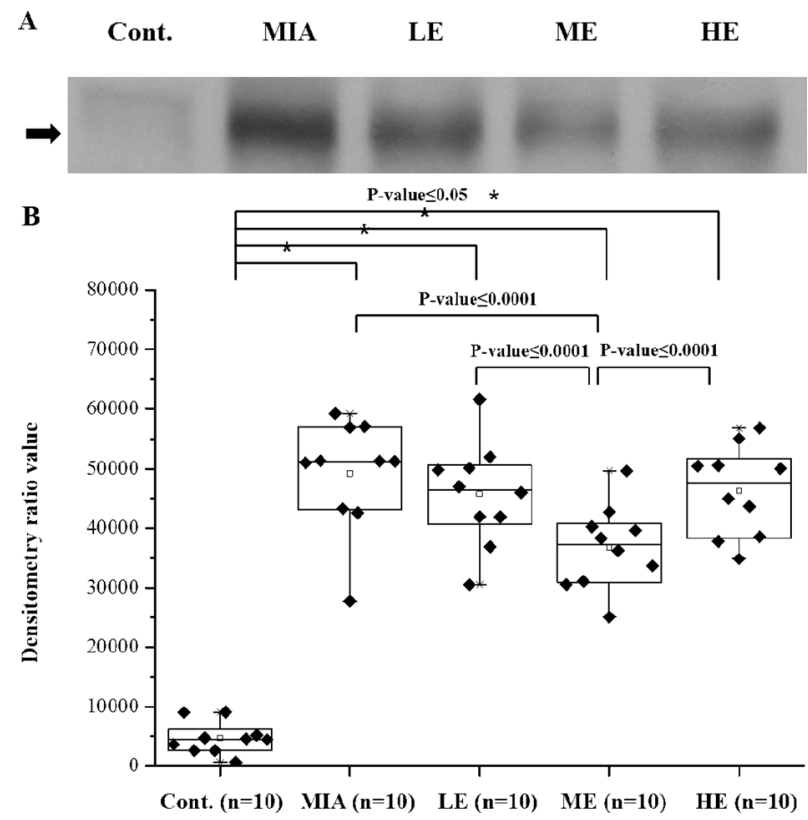

Fig. 1. Validation of C9 by Western blot and densitometry analysis. (A) Representative Western blot of crude sera from each group. (B) The Western blot data of the crude sera of 10 individuals from each group were subjected to densitometry analysis. The density and area of the bands of the Western blot were measured by using Scion Image, as described in the Materials and methods.

ever, whole serum protein analysis has limitations. Serum proteins exist in high dynamic ranges. Therefore, due to the masking effects of several highly abundant proteins, such as albumin and IgGs, proteins present at low levels that might be potential novel biomarker candidates, could not be detected. It appears to be necessary to discover more proteins with different serum preparation methods and to confirm them in human patients with OA.

It is not clear whether exercise is beneficial for OA improvement. Deeper investigation of the correlation between $\mathrm{OA}$ and exercise is needed. Also, many other different experimental methods could be used in the study of correlation between exercise and OA. One recent study suggested that the glycosamionoglycan content in cartilage increases after exercise ${ }^{21)}$, and another showed that increased muscle strength provides joint stability and reduces pain and disability $^{4}$.

Here, we showed that treadmill exercise could decrease the inflammatory response protein $\mathrm{C} 9$ in serum of an OA rat model, which demonstrates that appropriate intensity exercise might be beneficial for patients with OA.

\section{REFERENCES}

1) Petersson IF, Jacobsson LT: Osteoarthritis of the peripheral joints. Best Pract Res Clin Rheumatol, 2002, 16: 741-760. [Medline] [CrossRef]

2) Jordan KM, Arden N, Doherty M, et al.: EULAR Recommendations 2003: an evidence based approach to the management of knee osteoarthritis: report of a task force of the standing committee for international clinical studies including therapeutic trials (ESCISIT). Ann Rheum Dis, 2003, 62: 1145-1155. [Medline] [CrossRef] 
3) Røgind H, Bibow-Nielsen B, Jensen B, et al.: The effects of a physical training program on patients with osteoarthritis of the knees. Arch Phys Med Rehabil, 1998, 79: 1421-1427. [Medline] [CrossRef]

4) Deyle GD, Henderson NE, Matekel RL, et al.: Effectiveness of manua physical therapy and exercise in osteoarthritis of the kneeA randomized, controlled trial. Ann Intern Med, 2000, 132: 173-181. [Medline] [CrossRef]

5) Thorstensson CA, Henriksson M, Von Porat A, et al.: The effect of eight weeks of exercise on knee adduction moment in early knee osteoarthritis-a pilot study. Osteoarthritis Cartilage, 2007, 15: 1163-1170. [Medline] [CrossRef]

6) Jan MH, Lin JJ, Liau JJ, et al.: Investigation of clinical effects of high-and low-resistance training for patients with knee osteoarthritis: a randomized controlled trial. Phys Ther, 2008, 88: 427-436. [Medline] [CrossRef]

7) Le L, Chi K, Tyldesley S, et al.: Identification of serum amyloid A as a biomarker to distinguish prostate cancer patients with bone lesions. Clin Chem, 2005, 51: 695-707. [Medline] [CrossRef]

8) Malik G, Ward MD, Gupta SK, et al.: Serum levels of an isoform of apolipoprotein A-II as a potential marker for prostate cancer. Clin Cancer Res, 2005, 11: 1073-1085. [Medline]

9) Georges C, Vigneron H, Ayral X, et al.: Serum biologic markers as predictors of disease progression in osteoarthritis of the knee. Arthritis Rheum, 1997, 40: 590-591. [Medline] [CrossRef]

10) Pavelka K, Forejtová Š, Olejarova M, et al.: Hyaluronic acid levels may have predictive value for the progression of knee osteoarthritis. Osteoarthritis Cartilage, 2004, 12: 277-283. [Medline] [CrossRef]

11) Bruyere $\mathrm{O}$, Collette JH, Ethgen $\mathrm{O}$, et al.: Biochemical markers of bone and cartilage remodeling in prediction of longterm progression of knee osteoarthritis. J Rheumatol, 2003, 30: 1043-1050. [Medline]

12) Vilíım V, Olejarova M, Macháček S, et al.: Serum levels of cartilage oligomeric matrix protein (COMP) correlate with radiographic progression of knee osteoarthritis. Osteoarthritis Cartilage, 2002, 10: 707-713. [Medline]
[CrossRef]

13) Dunham J, Hoedt-Schmidt S, Kalbhen D: Prolonged effect of iodoacetate on articular cartilage and its modification by an anti-rheumatic drug. Int J Exp Pathol, 1993, 74: 283. [Medline]

14) Guingamp C, Gegout-Pottie P, Philippe L, et al.: Mono-iodoacetate-induced experimental osteoarthritis. A dose-response study of loss of mobility, morphology, and biochemistry. Arthritis Rheum, 1997, 40: 1670-1679. [Medline] [CrossRef]

15) Itoh $T$, Imano $M$, Nishida $S$, et al.: Exercise increases neural stem cell proliferation surrounding the area of damage following rat traumatic brain injury. J Neural Transm, 2011, 118: 193-202. [Medline] [CrossRef]

16) Uda M, Ishido M, Kami K, et al.: Effects of chronic treadmill running on neurogenesis in the dentate gyrus of the hippocampus of adult rat. Brain Res, 2006, 1104: 64-72. [Medline] [CrossRef]

17) Heo SH, Lee SJ, Ryoo HM, et al.: Identification of putative serum glycoprotein biomarkers for human lung adenocarcinoma by multilectin affinity chromatography and LC-MS/MS. Proteomics, 2007, 7: 4292-4302. [Medline] [CrossRef]

18) Liszewski MK, Farries TC, Lubun DM, et al.: Control of the complement system. Adv Immunol, 1996, 61: 201-283. [Medline] [CrossRef]

19) Konttinen YT, Ceponis A, Meri S, et al.: Complement in acute and chronic arthritides: assessment of $\mathrm{C} 3 \mathrm{c}, \mathrm{C} 9$, and protectin (CD59) in synovial membrane. Ann Rheum Dis, 1996, 55: 888-894. [Medline] [CrossRef]

20) Andersson ML, Thorstensson CA, Roos EM, et al.: Serum levels of cartilage oligomeric matrix protein (COMP) increase temporarily after physical exercise in patients with knee osteoarthritis. BMC Musculoskelet Disord, 2006, 7: 98. [Medline] [CrossRef]

21) Roos EM, Dahlberg L: Positive effects of moderate exercise on glycosaminoglycan content in knee cartilage: a four-month, randomized, controlled trial in patients at risk of osteoarthritis. Arthritis Rheum, 2005, 52: 3507-3514. [Medline] [CrossRef] 